\title{
Invasive Thymoma
}

National Cancer Institute

\section{Source}

National Cancer Institute. Invasive Thymoma. NCI Thesaurus. Code C6453.

A thymoma of any morphologic type that extends beyond the capsule and infiltrates the surrounding tissues. 